\title{
エンターテインメント機構としての都市 韓国における可能性に関する試論的な分析
}

\section{張 元晧}

\section{1 序論}

グローバル化は世界中に大きな変化をもたらした。経済の分野では「グローバル経済」 が形成され世界経済がリアルタイムで動くようになり，インターネットによるコミュニケ ーションの増加は世界中で平等志向のグローバル文化の拡大をもたらした。多くの研究者 の場合, このようなグローバル文化の拡大が政治の分野においても分権化を促し, この潮 流の下で地方政府も自立的な運営と均等発展が可能になると予想した。しかし結果は予想 に反し, 地域はいわゆる「世界都市 (global city)」としてグローバルネットワークに属 する地域とそれ以外の地域に二分化され，次第にその差は次々拡大され，世界各国は深刻 な地域不均衡の問題を抱えるようになった。

このような傾向は韓国でも見られ, 世界都市へ発展したソウルと発展から取り残された 地方都市との間に見られる不均衡問題が韓国社会の直面するもっとも深刻な問題となって いる。ノ・ムヒョン現政権はこの不均衡問題の解消に乗りだし,「国家均衡特別法」と「地 方分権特別法」を制定するなど地域不均衡是正のために独自的な政策を打ち出した。また， 「行政都市」建設は元来, 行政効率化の目的として実施されたものだが, 不均衡の是正に つながる可能性を持つものとして上記の政策と同一視してよいだろう。しかし，こうした 従来型の開発主義的な手法には限界があり,「行政都市」の建設によってかえって首都圏 とその他の地域との間に格差が拡大され，不動産投機を加熱させたために地方の発展を阻 害しているというのが実態のようである。

地方政府の発展と関連して最近注目されているのがエンターテインメント機構として の都市 (City as an Entertainment Machine) 理論である [Florida, 2002; Clark, 2004; Schachter, 1997]。この理論はアメニティーとエンターテインメントの要素を普及させ ることが地方政府の安定的な発展と革新をもたらすと主張するものである。これはエンタ ーテインメント産業の振興による経済的な効果という直接的な利益ではなく, エンターテ インメント都市としての性格を持つ地方政府であるほど創造的な住民たちが移住してくる ことに注目したものである。創造的な住民とは, 高学歴, 若年層, 専門家集団であり, 地 
域に新しい事業と雇用を創出するような集団を指す。イングルハート [Inglehart, 1990］ が主張したように, 彼らは過去の物質主義志向とは異なり, アメニティーとエンターテイ ンメントの要素に特に敏感に反応してこれを志向する地方政府を選好する集団といえよう。 つまり,「エンターテインメント機構としての都市論」の主張というのは, 地方政府が環 境と文化施設を拡充し, 観光産業を促進すると, 創造的な力を持っている集団が効果的に 移り住むようになり,これにもとづき地域発展に役に立つ安定的な人的, 物的基本構造を 築くことができるということである。

この議論を踏まえて, 本研究では韓国都市をエンターテインメント機構都市として分析 していく可能性を探る。このことによって, 韓国都市がエンターテインメント機構都市と して発展していく可能性について展望していきたい。まず，このような可能性を探る理論 的な土台として地域発展に関わる都市理論について議論する。具体的には既存の「成長機 構としての都市論」と「反成長機構としての都市論」を「エンターテインメント機構とし ての都市論」と比較する。特に, この理論が前提としている価值観と政治文化を検証する ことによって, 都市理論の発達過程でみられる「エンターテインメント機構としての都市 論」に注目し, 分析可能性を探る。次に, この可能性を題材に実証分析を行い, 試行的に 探ってみる。つまり,「エンターテインメント機構としての都市論」が言及している創造 的な集団が韓国でもアメニティー志向かつエンターテインメント志向的かどうかについて サーベイデータをもとに分析してみる。最後に自治体単位のアグリゲート・データにもと づき，いわゆる創造的な集団と地方政府の財政力との関係性を検討し，韓国でも創造的な 集団が地方政府の発展に有意な関連性を持っているのかどうかについて分析したい。

以上のように「エンターテインメント機構としての都市論」をとおして韓国社会を分析 していく可能性を探り，このことによって韓国の地方政府がアメニティーとエンターテイ ンメントを重視する政策転換を通して得られる効果, つまり, 創造的な集団の確保, 地域 発展の促進などを試論的に提示しようと考えている。

\section{2 地域発展に関わる都市理論}

本節では地域発展に関わる都市理論を三つの類型に分けて，それぞれの都市理論にみら れる政治文化的な特性と地方政府の属性をみることとしたい。

2-1 成長機構としての都市論（City as a Growth Machine）：開発志向的な政治文化 成長機構としての都市論の要旨とは，地域開発に密接な利害関係を持っている地域の不 動産所有者と開発業者で構成される「成長機構 (growth machine)」が, 開発を通した 利益を得るために地域の中で成長イデオロギーを作り, 開発志向的な政策を実施するとい うことである [Molotch, 1976; Logan and Molotch, 1987]。彼らはまずこの地域の人口 
成長及び経済規模の拡大に利益が一致するさまざまな団体の協力を得ようとする。例えば, 地域のマスコミや金融関連業者，公共設備の製造業者などが代表例として挙げられる。そ して成長機構はこうした団体とともに，地域開発的な政策決定に関与する政治家を自分た ちの勢力に引き入れようとする。このような行動は選出された政治家を対象に，地域開発 に関わるロビイングといった消極的な方法でも行われるが，多くの場合，自分たちの利益 を代弁する政治家たちを当選させ，再選できるよう支援するような積極的な方法を採るよ うにする。そして当選された政治家は成長機構の代弁者として，また成長政策の執行者と して役割を担うようになる。成長機構論では，成長機構である地域の不動産所有者や開発 業者だけではなく，一般住民にも地域開発が自分たちの利益につながると考えていること を前提している。例えば，地域発展が地域住民の雇用を生み出し，地域の不動産価値を上 げるものだと認識し，開発志向の政策にも同調することによって，結局，地域全体が一つ の大きな成長機構になると考えている。ただし，ローガンとモロッチは成長への同意は都 市全般にかかわることだが，成長の利益は都市の全住民に及ぶわけではないと述べている。 例えば，一般住民は成長を通して新しい雇用創出を期待しているが，地域住民が雇用され ることよりも外部から新たに移住してきた労働者が職に就くということが多いことが挙げ られる。この場合, 成長はむしろこの地域の空気や水の污染, 交通量の増加, 新住民の増 加による軒轢を招き，一般住民の生活環境は悪化されることになる。結局，成長の恵みは 大体初めに結成された初期成長機構に戻り，一般住民は無分別な開発が残した負担を負う 羽目になる [Logan and Molotch, 1987]。さらにもっと大きな問題は成長機構が究極的 に地方政府の規模と財政の拡大に結びつくことである。上で説明したように都市では成長 の結果, 新たな問題が起こり, 成長を支えた集団では解決できない公共財の問題として残 される。そのため成長機構の一部だった政府はさまざまな公共政策の拡大を通して負の遺 産の解決に取り組まなければいけない。これは政府規模や財政の恒常的な拡大を強いるも のであり，地方財政を逼迫させることになる。

「成長機構としての都市論」は開発志向的な政治文化の産物だといえる。開発志向的な 政治文化は地域の発展のために地方政府にたくさんの開発事業を実行させ，それによって 雇用創出のような経済的な効果をもたらすという理論である。このような政治文化は近代 化の過程で産業化と都市化が進行したことと密接な関連があり，マルクス主義学者たちは このような開発志向の政治文化を資本主義の発達過程と関連づけて説明している。例えば カステルは「集合的な消費 (collective consumption)」という概念を用い, 資本主義の 発達に伴って公共住宅や学校などの施設が必要になることを説明し，これを持続的な都市 成長と関連させて説明している [Castells, 1977]。ハーヴェイの場合，資本の循環理論を 通して開発志向的な政治文化を説明している。彼は生産と消費の過程だけでは資本の蓄積 が不可能であると述べている。いいかえると単純な生産の増加を通した資本の増加は結局, 資本価値の下落をもたらすというのだ。そして彼は資本価値の下落を防ぎ，実質的な資本 
蓄積を可能にするために，生産過程以外の領域に資本を投下する必要があると指摘してい る。つまり，このような資本投下は「建造環境（built environment）」に行われ，継続的 な開発志向政策に至ることになると説明している。[Harvey, 1982]。

また，「成長機構としての都市論」は物質主義的な価值観を持っている住民を想定して いる。すなわち，地域住民はガバナンスのような抽象的な問題というよりは雇用創出など の具体的な経済問題により強い関心を持っているということである。また，この理論は 受身でエリート依存的な住民の政治参加を想定している。いいかえると，住民は選挙の ような消極的な方法で政治に参加し，この結果，地域の経済的，政治的なエリート連合 体である成長機構がその情報力と経済力を背景に実質的な地域政策の決定者と執行者に なるというのだ。これはやがて地域政治家と地域経済エリートの間に後見主義的な関係 (clientelistic relationship) が形成され，地域の民主化を阻害する要因になることを意味 している。

2-2 反成長機構としての都市論（City as an Anti-Growth Machine）：ガバナンス志 向的な政治文化

1970 年代に入って米国の多くの地方政府が準破産（quasi-Default）状態に陥った。こ れは前述した成長志向的な開発政策の産物といえるが，開発を促進する中で浮上した問題 にもかかわらず，地方政府が公共政策を通してこの状態を解決するため，財政支出を行い， 地方財政を逼迫させたのが原因だと思われる。このような準破産は開発と福祉を同時に志 向する民主党出身の市長がいる都市においてはっきり現れており，その代表例としてニュ ーヨーク，バッファロー, クリーブランドなどを挙げることができる。

このような財政危機に対して地域住民は政府規模の縮小と政府財政の効率化を強く要求 するようになり，この要求に呼応した政治家たちが彼らと連合するようになるというの が「反成長 (Anti-Growth) 機構としての都市論」の要旨である [Clark and Ferguson, 1983; Clark and Goetz, 1994; Clark and Rempel, 1997]。この理論によると反成長機構 は新財政ポピュリスト（New Fiscal Populist）政治家と地域住民の連合によって誕生す るものである。新財政ポピュリストというのは政党と労組などの既存の政治組職に依存せ ず，地域住民に直接アピールすることによって当選された政治家である。そして彼らは地 域住民が要求するとおりに地方政府規模と地方財政の縮小及び効率的な支出のための政策 を行なうようになる。彼らが実際に行った緊縮政策の例としては，非効率的な部署の予算 削減や公務員人員の自然削減, 地方政府の事業の民間委託 (contract out), 都市マネージ ヤー (city manager) 制度を通した地方政府への企業的経営手法の導入などが挙げられる。

反成長機構としての都市論は地域住民の政治文化的な変化を前提としている。つまり, 地域住民は既存の消極的，受動的な政治参加で止まらず，エリートに対して挑戦的な態 度を見せつつ，より積極的に政策決定に参加するなど，いわゆるガバナンス志向的な政治 
文化を見せている [Clark, 1998; Lee and Jang, 2004]。この理論は，ガバナンス志向的 な政治文化が成長するようになったもっとも大きな要因として高等教育の普及と職業構造 の変化を挙げている。つまり, 高等教育が普及さればされるほど地域住民は政治エリート に従わず，政治エリートに挑戦して自分の選好を実現しようとする傾向が強くなるという のである。また，後期産業社会の発展によって第 2 次産業分野で働いているブルーカラ 一の数が減少する一方で専門職と技術職が増加していくことに起因する。このような専門 職・技術職に従事する人々の場合，ヒエラルヒー的な組織よりも平等で，水平的な組織を 選好する傾向が強く，ヒエラルヒー的な地方政府に対しても，その非効率性を批判するよ うになる。また，この理論は情報社会の発展がこのような傾向をさらに増幅させたと主張 する。すなわち，情報社会化によって地域住民の情報に対する接近性が増し，それにもと づいて政治エリートに挑戦し，彼らを牽制する政治文化が発達するようになったと指摘し ている。

2-3「エンターテインメント機構としての都市論」(City as an Entertainment Machine) : アメニティー志向の政治文化

20 世紀後半の政治的な争点は, イデオロギーや巨大思想から, 消費とライフスタイル 関連に変わってきた。新しいポップミュージック, 人気ある映画, 新型の車, テレビゲー ム，インターネット，スローフードのような一般人のエンターテインメントに関する議論 がますます政治と密接にかかわるものとして扱われてきた。

このような政治的な変化を背景に出現した理論が「エンターテインメント機構としての 都市論」である [Clark, 2004; Florida, 2002; Gottlieb, 1994]。この理論によると 20 世 紀後半からエンターテインメントをめぐるさまざまな議論が公共アジェンダを主導するよ うになり，政府は観光産業と文化産業の振興に力を入れるようになった。例えば，ニュー ヨークとシカゴでエンターテインメント産業は金融やパソコン産業よりも成長が速い産業 として位置を占めた。「マシン政治（machine politics）」の象徵だったシカゴの Daley 市 長も, 今は観光とエンターテインメントを通した都市発展を宣伝しながら, 自分の政治的 な立場を確固にしている [Clark, 2004]。

「エンターテインメント機構としての都市論」を唱える学者らは, エンターテインメン 卜要素こそが地域に発展をもたらすもっとも効果的な要因だと主張している。つまり，過 去の開発志向的な政治文化では地域の開発が雇用を創出し, 地域経済を活性させるという 論理を展開していた反面，エンターテインメント要素を強調する立場では，エンターテイ ンメントの増進こそが創造的な集団を地域内にとどめ置く要素だと主張している。また, この立場では創造的な力を備えた集団として若く, 高学歴で高所得者, さらには専門家と いった集団に注目し，このような集団がエンターテインメント要素にもっとも敏感に反応 し，エンターテインメント機構の役割を果たす地方政府を選好してその地域に移住すると 
説明している。そしてこの都市論では, 創造的集団が地域経済の活性化や地域の政治・社 会的な革新に貢献すると考えており，既存の地域発展に関わる因果関係を逆に捉える見方 といえよう。つまり, 既存の地域発展理論は雇用を創出して人口の増加をもたらすという 観点であったがこの都市論はエンターテインメント要素が創造的な力を持つ人々の流入を 促し，そのような人々がまた雇用を創出して地域が発展するという発想である。

「エンターテインメント機構としての都市論」はアメニティー志向の政治文化を前提と している。アメニティーは, 自然的アメニティーと建設された人工アメニティーの二つ に分けられる。まず，自然的なアメニティーとは言葉どおりに，自然がもたらす快適温 度，湿度，景色などである。もうひとつ，建設された人工アメニティーには，オぺラハウ ス，博物館，美術館，公園などのさまざまな文化施設などが含まれている。このような政 治文化的な変化をもたらしたもっとも大きな原因は価值観の変化である。つまり，人々の 価値観が経済的な安定を最優先する物質主義的な価值観（materialistic value）から質を 求める脱物質主義的な価值観（post-materialistic value）に変わったことで，人々は政治 的な領域でも雇用などの物質主義的な争点より，環境やアメニティー，文化的な争点によ り強い関心を持つようになったことを意味する [Inglehart, 1990]。

このような価值観的変化とともにインターネット革命による疎通性の増加はアメニティ 一志向的な政治文化をもたらす重要な役割を担当した。すなわち, 疎通性の増加は政治工 リートが一般市民の規則に従うように導き，アメニティーのような日常生活が政治的関心 と論議で重要な領域になるように導いたのである。

次頁の〈表 1〉に今までの議論を要約した。理解の手助けとして，今までの論議を〈表 1〉で整理しておくことにした。

本研究では今まで述べてきた三つの政治文化の中で「エンターテインメント機構として の都市論」に注目し，その視角から韓国都市を題材にその分析可能性を探ることにする。

\section{3 韓国のエンターテインメント機構に関する実証的分析}

本節では, 時系列データ分析を必要とする動態分析（特に人口の流入流出）は次の分析 課題とし, まずは都市の変数間の関係を静態的に分析することで「エンターテインメント 機構としての都市論」が韓国でどの程度当てはまるのかを試行的に探ってみる。

$3-1$ 仮説とデータ

「エンターテインメント機構としての都市論」は若い世代であれば豊かな時代に社会化 の過程を経験したためより脱物質的な価值を持つようになり，これによって生活の質を追 
表 1 成長機構, 反成長機構, エンターテイメント機構の比較 ${ }^{1)}$

\begin{tabular}{|c|c|c|c|}
\hline & $\begin{array}{c}\text { 成長機構としての } \\
\text { 都市論 } \\
\end{array}$ & $\begin{array}{c}\text { 反成長嘰構としての } \\
\text { 都市論 }\end{array}$ & $\begin{array}{l}\text { エンターテイメント } \\
\text { 機構としての都市論 } \\
\end{array}$ \\
\hline 価值観 & 物質主義的 & $\begin{array}{l}\text { 物質主義的 / } \\
\text { 脱物質主義的 }\end{array}$ & 脱物質主義的 \\
\hline 政治文化 & 開発志向政治文化 & $\begin{array}{l}\text { ガバナンス志向 } \\
\text { 政治文化 }\end{array}$ & $\begin{array}{l}\text { アメニティー志向 } \\
\text { 政治文化 }\end{array}$ \\
\hline $\begin{array}{l}\text { 政治文化を } \\
\text { もたらした } \\
\text { 社会的な構造 }\end{array}$ & $\begin{array}{l}\text { 資本主義の成長による産業 } \\
\text { 化と都市化 }\end{array}$ & $\begin{array}{l}\text { 高等教育の増加 } \\
\text { 専門職の増加 } \\
\text { 情報化の増加 }\end{array}$ & $\begin{array}{l}\text { 社会内の全般的な豊かさ } \\
\text { インターネットの発達 }\end{array}$ \\
\hline 主要な集団 & 高年齢, ブルーカラー & 高学歴，専門職 & $\begin{array}{l}\text { 低年齢, 高学歴, } \\
\text { 高収入, 専門職 }\end{array}$ \\
\hline $\begin{array}{l}\text { 主要な } \\
\text { 政治争点 }\end{array}$ & $\begin{array}{l}\text { 貨金, 雇用の創出のような } \\
\text { '生産政治' }\end{array}$ & $\begin{array}{l}\text { 低費用, 高効率 } \\
\text { 反成長, 公共管理 }\end{array}$ & $\begin{array}{l}\text { ライフスタイル } \\
\text { 質, 環境, 文化, } \\
\text { 日常生活などの消費政治 }\end{array}$ \\
\hline 地域発展観 & $\begin{array}{l}\text { 開発による雇用と優秀な人 } \\
\text { 材の確保が地域発展を主導 }\end{array}$ & $\begin{array}{l}\text { 経営の手法を元にする効率 } \\
\text { 的な公共管理が地域発展を } \\
\text { 主導 }\end{array}$ & $\begin{array}{l}\text { アメニティーとエンターテ } \\
\text { イメントの拡大による革新 } \\
\text { カ量の確保が雇用と革新的 } \\
\text { な方式を創出して地域発展 } \\
\text { を主導 }\end{array}$ \\
\hline
\end{tabular}

求するアメニティー志向文化を持つようになると主張している。このような傾向は教育水 準が高い集団であるほど，また，所得水準が高い集団で，専門家集団であるほどより強く 現われる。このような議論に限ってエンターテインメント機構の志向性と人口学的な変数 との関係を仮説として設定すると，次のようになる。

〈仮説 1 若年層で, 所得水準や教育水準が高く, 専門家集団であるほどエンターテイン メント機構志向である。

「エンターテインメント機構としての都市論」の主張は先述のような集団であるほど, この地域経済の活性化をもたらし，究極的には地域の革新が達成されるというのである。 地域の革新は政治, 経済, 社会, 文化といった分野の革新を包摂している。ただ，ここで はデータの制約があるためエンターテインメント機構の志向集団と地域経済の活性化の関 係に限って検証する。具体的な仮説は次のようになる。

〈仮説 2〉若年層, 高所得, 高学歴, 専門家集団が多い地域の地方政府ほど, 地域経済の 
活性化を達成することができる。

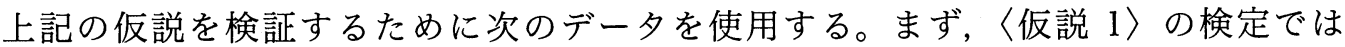
2003 年に実施された韓国社会調査（Korea General Social Survey，KGSS）を使用する。 KGSS は教育部のプロジェクトで, アメリカ・シカゴ大学の全国世論調査センター（National Opinion Research Center, NORC) の GSS (General Social Survey) と同じ方式で構成されて いる。また，〈仮説 2〉の検証では 2000 年人口調査と 2004 年韓国地方行政年鑑を主に利 用して構成したアグリゲート・データを使うことにした。

\section{$3-2$ 分析結果と解釈}

(1) 一般市民の政府財政支出に対する評価

本研究はまず政府支出の各項目に対する一般市民の評価を利用して分析した。この結果 を〈表 2〉に示す。まとめてみた〈表 2〉に表示されている数字は政府の財政支出項目別に， 各項目の財政支出が今より増額すべきかどうかに対する一般市民の回答平均值である。例 えば，平均值が 3 点満点中 2 点となった場合，概ね一般市民は政府が現在の支出水準が 適当だと考えているということになる。点数がこれ以上ならば一般市民はさらなる政府の 財政支出を要求していることを意味する。

この表をみると国防支出を除いたすべての項目で高い平均値を示していることから，一

表 2 項目別国家支出に対する評価の平均値

\begin{tabular}{lll}
\hline \multicolumn{1}{c}{ 支出項目 } & 平均 & $\mathrm{N}$ \\
\hline 保健衛生 & $2.60(.59)$ & 1287 \\
人口過密抑制 & $2.30(.71)$ & 1218 \\
犯罪抑制 & $2.59(.55)$ & 1223 \\
教育 & $2.55(.63)$ & 1241 \\
社会福祉 & $2.74(.48)$ & 1289 \\
大衆交通 & $2.43(.58)$ & 1276 \\
児童保育 & $2.64(.61)$ & 1253 \\
環境 & $2.62(.58)$ & 1272 \\
文化施設 & $2.48(.59)$ & 1277 \\
国防 & $1.82(.68)$ & 1221 \\
\hline
\end{tabular}

注：項目別評価值 $\quad(1=$ 縮小 $2=$ 維持 $3=$ 拡大 $)$

括弧内は標準偏差。

出所 : 2003 年 韓国総合社会調査 (KGSS) 
般市民は依然として政府支出をもっと増やすべきであると考えていることがうかがえる。 つまり，まだ開発志向的な政治文化志向性を持っているといえよう。これにはさまざまな 理由が考えられるが，重要な理由として韓国がいまだ福祉国家になっていないと考えてい る人が多いという点が挙げられる。これは〈表 2〉の社会福祉について, さらに多くの支 出を要求していることからもこのような見方は妥当だともいえるのではないか。

(2) 一般市民の人口社会学的な特性とエンターテインメント機構の志向性

次に一般市民の人口社会学的な特性とエンターテインメント志向性との関係を分析する。 財政支出の選好関連項目について二つの財政支出選好の従属変数をリッカート尺度法で作 成した。二つの変数に関する説明は次のとおりである。

－FISAVG（一般財政支出選好）：この変数はKGSS の 10 個の国家支出項目に対す る評価のうち，国防，環境，文化施設に対する評価を除外した 7 項目の評価の平均 值である。この変数は財政支出の増加に賛成する程度であり, 開発志向的な政治文化 を持つ住民であるほど高く現われ，財政的な効率性を追求する住民であればこの変数 に対する変数值は低くなる。

－ENTERTAIN（エンターテインメント支出選好）：この変数はKGSS の 10 個の国 家支出項目に対する評価のうち，環境，文化施設に対する評価の平均值である。こ の変数は上記の「一般的な財政支出選好 (FISAVG)」変数よりも構成項目数が少ない が, 環境という自然的なエンターテインメント要素と文化施設という人工エンターテ インメント要素が含まれているため, エンターテインメント機構に対する選好度をよ く示す変数といえる。この変数值が高いほどエンターテインメント志向性が強いとい える。

まず, 人口社会学的な変数とエンターテインメント機構志向性との関係を調べるために 相関分析を実施した。この結果が〈表 3〉に示されている。

表 3 一般市民の人口的属性とエンターテイメント機構志向性

\begin{tabular}{clll}
\hline & 教育 & 年齢 & 収入 \\
\hline FISAVG & $.221^{* * *}(1305)$ & $-.161^{* * *}(1303)$ & $.135^{* * *}(1256)$ \\
\hline ENTERTAIN & $.230^{* * *}(1292)$ & $-.165^{* * *}(1292)$ & $.119^{* * *}(1244)$ \\
\hline
\end{tabular}

注：すべての係数はPearson 相関係数。括弧内は有効標本数。

収入変数值は実際収入を自然対数に変換した值。

有意水準 $(\mathrm{p}):{ }^{* * *}<.001$

出所 : 2003 年 韓国総合社会調查 (KGSS) 
〈表 3〉で見られるように教育水準が高く，年齢が低く，また収入が高いほど，一般的 な財政支出を選好する傾向が現われた。これは反成長機構的な立場からみると予想外の結 果といえる。つまり，反成長機構的な立場では教育水準が高く ${ }^{2)}$, 高所得集団であるほど， 効率的な政府を志向するとみられる。これは財政支出の縮小を要求することを意味するが, 韓国の場合はこれとは反対の結果が出された。このような結果は先述のものと同様に，住 民の中で韓国はまだ福祉国家になっていないという認識が強く現れたと考えられる。

また，エンターテインメント志向に関しては仮説を支持する結果が得られた。つまり， 教育水準が高く，若年層で，収入が高いほどエンターテインメントと関連している財政支 出に対する選好度が高い。このような結果は低年龄, 高学歴, 高所得集団が福祉国家を達 成するために一般的な財政支出の増加を選好することと同じ理由で，エンターテインメン 卜財政支出を選好しているのだと思われる。しかし，〈仮説 1〉をもっと説得的に検証す るためには，上記の集団がエンターテインメント財政支出に対して拡大要求志向性を持っ ているかどうかを一般財政支出とは別途に立証する必要性がある。

このため,このような集団の属性に対するさらなる綿密な分析を行わなければならな い。上で提示した相関分析は, 韓国の場合世代別に，また大学教育を受けたかどうかによ って価値観と志向性が大きく異なることを見過ごして，教育と年齢，収入の影響力が線形 的であるという仮定で分析しているという限界を持っている。まず年齢をみると韓国では いわゆる「386 世代」とこれ以前の世代との間に価值観の内容的な断絶がある。386 世代 というのは1960年代に生まれ, 反独裁闘争期だった 1980 年代に大学時節を過ごした人々 のことで，反独裁民主化運動と密接な関連がある世代である。仮に大学を通っていなかっ た人々でも，社会の全般的な雾囲気が民主化を望むものであったことから，この世代の全 般的な特徵として民主主義を志向する自由主義的な志向性をあげることができる。さらに， 386 世代の場合，経済的には米国中心の新自由主義に対する拒否感情を持っており，依然 として社会福祉関連の支出拡大といった経済的な平等を求めるイデオロギー的な特徵を持 っていた。よって，386 世代は福祉国家を実現するような財政支出を選好するものである と予測される。

これに対して，20 代はすでに民主化された環境の中で社会化された世代であるため, 386 世代よりも個人主義的で生活の質に対する強い関心を示す。また，彼らは情報化とグ ローバル化が急速に進展した 1990 年代に青少年期を過ごしたため, 国際的な文化に慣れ ている世代である。そして 20 代ではエンターテインメント機構志向性がもっとも明確に 現われるようになったと予想される。

このような点を考慮して本研究では年齢を単純に間隔変数で見ずに 20 代集団, 386 世 代集団，また 50 歳以上の既成集団という三つのカテゴリーに分けて追加的な分析を実施 した。386 世代は 2003 年の調査では 34 歳から 44 歳までの集団とし, 30 歳から 32 歳, 44 歳から 49 歳の集団は過渡的（または中間的）性向を持っていると考えたため，今回 
表 4 世代別財政支出選好の平均

\begin{tabular}{lcc}
\hline & FISAVG & ENTERTAIN \\
\hline 20 代 & $2.56(279)$ & $2.63(276)$ \\
386 世代 & $2.60(394)$ & $2.54(392)$ \\
50 代以上 & $2.43(355)$ & $2.42(350)$ \\
統計的に有意な & 20 代. 386 世代 vs. 50 代以上 & 20 代 vs. 386 世代 \\
平均の差 $(p<.05)$ & 386 世代 vs. 50 代以上 \\
\hline
\end{tabular}

注：括弧内は有効標本数。

出所：2003 年 韓国総合社会調查 (KGSS)

\section{表 5 教育水準別財政支出選好の平均}

\begin{tabular}{lcc}
\hline & FISAVG & ENTERTAIN \\
\hline 大在以上 & $2.60(416)$ & $2.65(415)$ \\
高卒以下 & $2.50(727)$ & $2.47(716)$ \\
平均の差 $(t$-test) & $.10^{* * *}$ & $.18^{* * *}$ \\
\hline
\end{tabular}

注：括弧内は有効標本数。

有意水準 $(\mathrm{p}):{ }^{* * *}<.001$

出所：2003 年 韓国総合社会調査 (KGSS)

の分析から除いた。世代別にみられる財政支出選好を比較した分析の結果を〈表 4〉にま とめた。

予想した通り〈表 4〉は〈表 3〉とは異なる結果を見せた。上記の〈表 3〉の結果のよ うに 20 代と 386 世代は，50 代以上の世代よりも一般財政支出とエンターテインメント に関する支出の増加を選好している。しかし，エンターテインメント財政支出に対する 志向性としては 20 代と 386 世代の間に開きがある。つまり，一般財政支出に関して 386 世代が支出增加をもっとも強く選好しているが，エンターテインメント財政支出に関して は20 代が一番支出増加を望んでいることがうかがえる。また，エンターテインメント財 政支出に対する選好度の平均をみると，20 歳代では，50 歳代だけでなく，386 世代にく らべても，有意に高い。すなわち，20 代は 20 代以外の世代と異なり，エンターテイン メント志向性がもっとも強く, これは〈仮説 1〉を支持する結果といえょう。

次に, 教育水準の中で大学教育の影響力を分析する。ここでも大学経験の可否が重要な 要因だと判断したため, 標本を大学在学の経験がある人と高卒以下の学歷である人という 二つの集団に分けて分析した。2 年制大学の経験者は先の年齢と同じく過渡的な価值観が 見られると判断して, 分析から除いている。教育をダミー変数で分けて分析した結果を 〈表 5〉に整理した。

〈表 5〉でもエンターテインメント志向性と大学教育との関係が見られる。まず〈表 3 〉 で見られたように大学教育を受けた集団は高卒以下の学歴を持つ集団よりも一般的な財政 
表 6 専門家集団と財政支出選好変数の関係

\begin{tabular}{ccc}
\hline & FISAVG & ENTERTAIN \\
\hline 専門家 $(n=100)$ & $2.66(100)$ & $2.69(99)$ \\
その他 $(n=1215)$ & $2.55(1210)$ & $2.54(1198)$ \\
平均の差 & $.11^{* *}$ & $.15^{* *}$ \\
\hline
\end{tabular}

注：括弧内は有効標本数。

有意水準 $(p):{ }^{* *}<.01$

出所 : 2003 年 韓国総合社会調査 (KGSS)

支出とエンターテインメント財政支出を選好している。そして，この選好の差は一般財政 支出が.10である反面，エンターテインメント財政支出は.18であることから，エンター テインメント財政支出に対する選好がより高いことがわかる。つまり, 大学教育を受けた 集団は高卒以下の教育を受けた集団よりもエンターテインメント機構志向性が強いと判断 される。これは〈仮説 1〉を支持する結果である。一方，収入とエンターテインメント機 構志向性の関連については〈表 3〉の結果以外に統計的な有意差を示す集団は見当たらな かった。

続いて, 職業とエンターテインメント機構志向性との関係について調べた。ここでは特 に専門職従事者のエンターテインメント機構志向性を検証する。このために市民集団を専 門職従事集団とこれ以外の職業集団に分けて，二つの集団の平均の差を検証する $\mathrm{T}$ 一検定 を実施した。

その結果を〈表 6$\rangle$ に示したが, ここでも反成長機構論の予測とは違う結果が表れてい る。つまり, 専門職従事者はその他の職業従事者よりも一般支出の増加を選好しているこ とが分かる。これに対しては，前に述べたように専門家集団も韓国の福祉国家水準に対し て懐疑的な立場に立ち，福祉支出を増やすべきだという意見を持っている人びとが多いと 説明する事ができる。エンターテインメント財政支出については〈仮説 1 〉が予想した通 り，専門職従事者であるほどエンターテインメント財政支出を選好するという結果を見せ た。しかし，これも福祉支出選好の延長線として理解できょう。専門職集団とこれ以外の 集団との間に現す財政支出の平均の差をみるとエンターテインメント財政支出が.15 で一 般支出の.11 よりも高いことが分かる。つまり, 専門家集団は他の職業従事者と比べて一 般的な財政支出の増加を選好しているが, エンターテインメント財政支出についてはさら に増やすことを求めていることが分かる。これは〈仮説 1〉を支持する結果である。

(3) エンターテインメント機構志向集団と都市財政との関係

続けて「エンターテインメント機構としての都市論」が主張する通り, 若年層で高学歴, 高所得, 専門家の集団が地方政府の財政活性化と地方政府の革新をもたらすのかどうかに 
表 7 基礎自治体のエンターテイメント機構志向集団と都市財政との相関係数

\begin{tabular}{lcccccc}
\hline & $20-30$ 代 & 大卒以上 & 専門職率 & 財政自立度 & 財政力指数 & 人口規模 \\
\hline $20-30$ 代 & 1.000 & $.593^{* * *}$ & $.583^{* * *}$ & $.638^{* * *}$ & $.549^{* * *}$ & $.692^{* * *}$ \\
大卒以上 & & 1.000 & $.826^{* * *}$ & $.670^{* * *}$ & $.481^{* * *}$ & $.674^{* * *}$ \\
専門職率 & & & 1.000 & $.622^{* * *}$ & $.532^{* * *}$ & $.626^{* * *}$ \\
財政自立度 & & & & 1.000 & $.715^{* * *}$ & $.674^{* * *}$ \\
財政力指数 & & & & & 1.000 & $.532^{* * *}$ \\
人口規模 & & & & & & 1.000 \\
\hline
\end{tabular}

注：すべての係数は Pearson 相関係数。

実際人口数を自然対数に変換した值。

有意水準 $(\mathrm{p}):{ }^{* * *}<.001$

出所 : 2000 年 人口住宅総調査, 2004 年地方行政年鑑

ついて分析する。〈仮説 2〉を証明するために財政自立度と財政力指数という地方政府の財 政変数を使用した。もちろん, この二つの変数が地方政府の財政活性化を測定するために 必要十分な変数だとはいえない。ただ，ここでは試論的な議論のための検証であり，二つ の変数が財政活性化を測定する変数として設定して議論を展開したい。まず，上で証明さ れたエンターテインメント機構志向集団と財政活性化との関係を調べるため, pearson 相 関分析を実施した。この分析は，2000 年人口調査と 2004 年地方行政年鑑の自治体単位の アグリゲート・データにもとづいて行われた。この分析で都市住民の収入は変数から除い ているが, これは財政自立度と財政力指数が都市住民の収入とあまりにも密接な関係があ るため計量分析上同じ変数を投入することと等しい結果になるためである。さて, 各集団 の財政活性化変数との相関関係を〈表 7 〉示した。

〈表 7〉で見られるようにエンターテインメント機構志向集団の比率が高い地方政府で あるほど財政活性化程度が高い。つまり，20-30 代比率が高いほど，また，大卒以上の高 学歴者の比率が高いほど, 専門職従事者の比率が高いほど, 財政自立度と財政力指数は高 い。これは〈仮説 2〉を支持する結果である。

〈表 7〉を解釈するとき第 3 変数による疑似相関 (spurious relation) が生じうることに 注意を払うべきである。すなわち，このすべての相関関係の原因が〈都市化程度〉という

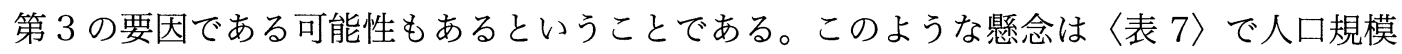
とその他変数との関係を調べてみると, 全て強い正の関係が見られることからも説明する ことができる ${ }^{3)}$ このような点で，〈仮説 2〉をより確実に（robust）検証するためには 多変量分析が必要だと思われる。しかし多変量分析を実施するためにこうした変数を一つ のモデルに含めてしまうと，互いに高い相関関係による多重共線性（multi-collinearity） の問題が発生する難点がある。そのため本研究では, 人口規模をもとに〈都市化程度〉変 数の影響力をコントロールするが，これを一つのモデルの中でコントロールせず，人口規 
表 8 基礎自治体の規模別エンターテイメント志向性集団と財政自立度間の相関関係

\begin{tabular}{ccccc}
\hline 人口規模 & $20-30$ 代 & 大卒以上 & 専門職率 & $\mathrm{N}$ \\
\hline $\begin{array}{c}\text { 下位 25\% } \\
\begin{array}{c}35,830 \text { 人以下) } \\
\text { 中位 50\% (Inter- Quartile }\end{array}\end{array}$ & $.284^{*}$ & $.291^{*}$ & $.218 \mathrm{a}$ & 58 \\
$\begin{array}{c}\text { Range) } \\
(35,831-174,465 \text { 人) } \\
\text { 上位 25\% }\end{array}$ & $.537^{* * *}$ & $.485^{* * *}$ & $.434^{* * *}$ & 116 \\
$(174,466$ 人以上 $)$ & .106 & $.451^{* * *}$ & $.440^{* *}$ & 58 \\
\hline
\end{tabular}

有意水準 $(\mathrm{p}):{ }^{* * * *}<.001,{ }^{* *}<.01,{ }^{*}<.05, a<.10$

出所：2000 年 人口住宅総調査, 2004 年地方行政年鑑

模別に標本を分けて別々に分析する方法を用いた。この結果は〈表 8〉のとおりである。

〈表 8〉は地方政府を人口規模別に下位 25\%，上位 25\%，また中位（Inter-Quartile Range) 50\% で三等分してそれぞれエンターテインメント機構志向集団と地方自治体の財 政自立度との関係の分析結果を示している。〈表 8〉をみると, 人口の多い地方政府におけ る〈20-30 代〉の比率と財政自立度との関係を除いて，どの人口規模の地方政府でも エンターテインメント機構志向集団の比率が高いほど財政自立度が高いという結果があら われた。

特に, 人口中位 $50 \%$ の口規模に当たる都市で若年層, 大学卒業以上の集団, 専門職 従事者の影響力が一番大きく現れたことはとても意味深い結果である。なぜなら，ほとん ぞの地方都市は人口規模から見た場合，中位層に当たるが，この結果はエンターテインメ ント志向集団の影響力が地方都市で一番強く作用するということを表しているからである。 これは, エンターテインメント機構としての都市が, 韓国の地域不均衡の解消に大きく寄 与しうるのではないかという点で，政策的重要性が高い結果だといえる。

〈表 7〉と〈表 8〉との結果から分かるようにエンターテインメント機構志向集団は地 方政府の財政自立度を増加させ，ひいては地方の財政活性化をもたらす要因として作用す るものと捉えられよう ${ }^{4)}$ 。

結論として，韓国の場合若年層で高学歴，高所得，専門家という集団はエンターテイン メント機構を志向する傾向が強いということがいえ，また彼らが地方財政活性化のための 重要な要因となっているようである。

\section{4 結論}

本研究では韓国都市をエンターテインメント機構都市として分析していく可能性を探る ことによって, 韓国都市がエンターテインメント機構都市として発展していく可能性を論 
じた。一般的にエンターテインメント機構は観光と文化産業による地域経済の活性化を意 味するが, 本研究ではエンターテインメント機構としての地方政府が革新的な力を持つ集 団の流入を促進し，この集団によって地方政府の䪊が促進するということに主眼を置い ている。そしてこのような主張を実証するために，韓国総合社会調査と人口センサス，ま た地方政府のアグリゲート・データを利用して若年層, 高学歴層, 高収入集団, 専門家集 団がエンターテインメントとアメニティー志向的であり, 地域経済の活性化をもたらす可 能性を提議した。特に，人口規模を統制した分析で，地方都市でのエンターテインメント 志向集団と地域経済の活発化の関係が一番高く現れた点からわかるように，韓国社会の一 番大きい問題である地域不均衡を解決するのにエンターテインメント機構としての都市が 大きく寄与することが予測される。

ただ入手可能なデー夕に制約があることによって，本研究の検証はきわめて限定的なも のとなったことは否めない。しかし，このような結果で見る限り西欧と同じく韓国でも若 年層, 高学歴層, 高収入, 専門家の集団においてアメニティーの政治文化は成熟しており, 彼らはエンターテインメント要素を重視する地方政府を求めているといえる。もちろん韓 国では福祉国家を切望する開発志向的な政治文化がなお強いことも否定できないが, 今後 韓国の地方政治がエンターテインメントを志向する政治の方向で発展するという予想は概 ね正しいと考えている。これは 20 代以下の若年層がエンターテインメント志向性を持っ ていることからも確信できる。社会の変化が速く進む韓国の社会的な状況では，このよう に新しい世代で発見される志向性は大変速く伝播する可能性が高いからである。

今後の課題としては静態的なデータだけではなく, 時系列データも使い, より精密な検 証を行う必要があると思われる。例えばここでは都市の変数間の関係を静態的に分析する ことによって「韓国都市をエンターテインメント機構都市として分析していく可能性」を 探ったが, 今後では人口の流入流出などの動態分析も含め, アメニティー志向的な集団の 流入を検証する必要がある。また, 財政支出選好度と関連して一般的な政府財政支出に対 する選好度項目を用いたが，それよりも地方政府の財政支出に対する選好度項目を用いる 方がより適切であろう。財政活性化変数についても, 既存の財政自立度や財政指数よりも 理論的により適切な新しい指標を作ることが必要である。

本研究で検証できなかった因果関係に対する検証も今後の研究課題である。特にアメニ ティーを志向し革新的な力を持つ集団と地方政府の財政活性化の間の因果関係を検証する 作業が必要である。つまり，革新的な力を持つ集団が地方政府の財政活性化をもたらした のか，それとも逆に財政活性化が実現しうる地方政府が革新的な力を持つ集団を誘引した のかについてはさらに適切な分析が要るだろう。

このように因果関係と関連する検証とともに革新的な力を持つ集団が地方政府の革新を 促す過程に対する具体的な分析も今後重要な研究課題といえる。例えば，地方政府がアメ ニティーやエンターテインメントの環境を拡充すれば, アメニティーの政治文化を志向す 
る集団がこのような地方政府の管轄区域に移住してくるのか，また移住を促すためにはど れほどのアメニティーやエンターテインメント要素の拡充が必要なのかについて，さらな る具体的な研究が求められる。

注

1）本研究は次の三つの政治文化が相互排他的（Mutually exclusive）なものではなくそれぞれの 視角から見たモデルだとみる。特に，ガバナンス志向の政治文化とアメニティー志向の政治文化 は地域住民が政治的公論で重要な役割をはたしている点などの一部共通点をもっている。しかし， 本研究は政治文化に関する論議を生み出すために多少無理な一般化の危険性を勘案し, 地域住民 の政治文化を三つに区別しその特徵を比較してみた。

2）すべての相関係数で有意性が現れ，值をみると全体的に高くはないものの，分析データが個人 水準の意識調査であるため，この数值が極めて低い相関係数だということはできない。

3）人口規模は都市化程度の重要な尺度で一つである。

4）ここで,〈表 7〉と〈表 8〉の結果は相関関係を基にしたため, 〈仮説 2〉が示す因果関係を十 分に検証することはできなかった。つまり，先の分析を通して革新的な力を持つ集団と地方政府 財政活性化の関係は証明できたが，〈仮説 2〉が主張する通り革新的な力を持つ集団が地方政府 財政の活性化をもたらしたのか, それとも財政活性化が実現しやすい地方政府であるほど革新的 な力を持つ集団を誘引したのかについては証明できなかった。このような因果関係に対する分析 は今後の重要な研究課題の一つと考えている。

\section{参考文献}

Castells, Manuel. 1977. The Urban Question. A Marxist Approach (trans: Alan Sheridan). London: Edward Arnold.

Clark, Terry Nichols ed. 2004. The City as an Entertainment Machine. Oxford: Elsevier.

Clark, Terry Nichols ed. 1994. Urban Innovation: Creative Strategies in Turbulent Times. London: Sage.

Clark, Terry Nichols and Vincent Hoffman-Martinot eds. 1998. The New Political Culture. Boulder, Colo: Westview Press.

Clark, Terry Nichols and Mike Rempel eds. 1997. Citizen Politics in Post-Industrial Societies. Boulder, Colo: Westriew Press.

Clark, Terry N. and Edward G. Goetz. 1994. 'The Anti-Growth Machine: Can City Governments Control, Limit, or Mange Growth?" in Terry Nichols Clark ed., Urban Innovation: Creative Strategies in Turbulent Times. London: Sage.

Clark, Terry Nichols and Laura Ferguson. 1983. City Money: Political Processes, Fiscal Strain and Retrenchment. New York: Columbia University Press..

Florida, Richard. 2002. The Rise of the Creative Class. New York: Basic Books.

Gottlieb, Paul. 1994. "Amenities as an Economic Development Tool: Is there enough evidence?' Economic Development Quarterly, 8(3) : 270-285.

Harvey, David. 1982. The Limits to Capital. Chicago: University of Chicago Press.

Hood, Christopher. 1991. "A Public Management for All Seasons?" Public Administration, 69: 3-19.

Inglehart, Ronald. 1990. Culture Shift. Princeton: Princeton University Press. 
Jang, Wonho. 1999. “Three-Nation Comparison on Mayors' Policy Preferences: Korea, Japan and the USA," International Journal of Urban Studies, $3(2)$ : 168-178.

Jang, Wonho. 1997. "The New Political Culture, Changing Policy Preferences of Mayors, and Changes of Urban Policies in Japan," Korea Journal of Population and Development, 27 (2) : 55-78.

Lee, Seung-Jong and Wonho Jang, 2004. "Factors Influencing Mayoral Leadership in Korea," International Journal of Urban Sciences, 8(1): 1-12.

Logan, John R. 1976. "Industrialization and the Stratification of Cities in Suburban Regions," American Journal of Sociology, 82-2: 333-348.

Logan, John R. and Harvey L. Molotch. 1987. Urban Fortunes: The Political Economy of Place, Berkeley: University of California Press.

Molotch, Harvey L. 1976. "City as a Growth Machine: Toward a Political Economy of Place," American Journal of Sociology, 82-2: 309-332.

Peterson, P. E. 1981. City Limits. Chicago: The University of Chicago Press.

Schachter, Hindy Laurer, 1997. Reinventing Government or Ourselves: The Role of Citizen Owners in Making a Better Government. Albany, New York: State University of New York Press.

(Jang, Wonho ノソウル市立大学都市社会学科教授) 